\title{
Morphological Characterization of Advanced Mutant Lines of Oat (Avena sativa L.)
}

\author{
Kavita Gupta* and A.K. Mehta \\ Jawaharlal Nehru Krishi Vishwa Vidyalaya, Jabalpur-482004 (Madhya Pradesh), India \\ *Corresponding author
}

A B S T R A C T

Keywords

Characterization, Recurved

Article Info

Accepted:

04 October 2018

Available Online:

10 November 2018
The present study was carried out to estimate the extent of variation for qualitative traits for advanced mutant generations of oat. Observations were recorded for the different agro-morphological characters viz., plant growth habit, ligule shape, leaf blade hairiness, leaf blade hairiness, recurved flag leaves, stem width, leaf width, leaf color, panicle attitude. Characterization of accessions provides the important information about morphological and agronomical aspects of the material that is essential for gene bank management.

\section{Introduction}

Oat is one of the major cereal crops in the world. It is ranked sixth after wheat, maize, rice, barley and sorghum. The oat fodder is a major livestock feed and its grain is also used widely for human consumption, as a source of valuable nutrients. Most cultivated varieties of oat belong to an allohexaploid species with $2 n=6 x=42$ chromosomes originated from the aggregation of three ancestral diploid genomes AA, CC, DD (Rines et al., 2006).

Oat is rich in the antioxidants $\alpha$ - tocotrienol, $\alpha$-tocopherol, and avenanthramides, as well as total dietary fiber including the soluble fiber $\beta$-glucan (Oliver et al., 2010). Assessment of the genetic variability can be achieved using morphological measurements and phenotypic characterization (Greene et al., 2008) also
Arora et al., (2008) carried out evaluation and characterization for some morphological traits in 554 germplasm accessions of oat.

\section{Materials and Methods}

\section{Experimental site}

The experiment was carried out under All India Coordinated Research Project on Forage Crops, Department of Genetics and Plant Breeding at Seed Breeding Farm, College of Agriculture, Jawaharlal Nehru Krishi Vishwa Vidyalaya, Jabalpur (M.P).

\section{Experimental Material}

The experimental material comprises of 115 mutant lines of oat along with three checks JO-1, JO 03-91 and Kent. 


\section{Observations recorded}

Following observations were recorded at appropriate growth stages.

\section{Agro-morphological observations}

Qualitative characters were observed on single plant per plot basis and were recorded. Different categories of characters were given in Table 1.

Plant Growth habit: At juvenile stage angle of tillers from the vertical is recorded.

Ligule shape: The shape of papery membrane inside junction between leaf sheath and blade was recorded.

Leaf sheath hairiness: Hairs on lowest leaf sheath was recorded.
Leaf blade hairiness: Hairiness of leaf blade margin below flag leaf was recorded.

Recurved flag leaves: Frequency of plants with recurverd leaves are recorded.

Stem width:

Stem thickness was recorded.

Leaf width: Leaf broadness was recorded.

Leaf colour: Colour of leaf was recorded

Panicle attitude: Angle of panicle from the vertical axis was recorded.

\section{Results and Discussion}

The 118 mutant oat lines including three checks were classified on the basis of morphological characters.

Table.1 Different categories of nine morphological characters

\begin{tabular}{|c|c|c|}
\hline Characters & Categories or type & Symbols \\
\hline 1. Plant Growth habit & $\begin{array}{l}\text { 1. Erect } \\
\text { 2. Intermediate } \\
\text { 3. Prostrate }\end{array}$ & $\begin{array}{l}\mathrm{E} \\
\mathrm{I} \\
\mathrm{P}\end{array}$ \\
\hline 2. Ligule shape & $\begin{array}{l}\text { 1. Pointed } \\
\text { 2. Broad edge }\end{array}$ & $\begin{array}{l}\mathrm{Pt} \\
\mathrm{Bi}\end{array}$ \\
\hline 3. Leaf sheath hairiness & $\begin{array}{l}\text { 1. Absent } \\
\text { 2. Weak } \\
\text { 3. Medium } \\
\text { 4. Strong }\end{array}$ & $\begin{array}{l}\text { A } \\
\text { W } \\
\text { M } \\
\text { S }\end{array}$ \\
\hline 4. Leaf blade hairiness & $\begin{array}{l}\text { 1. Absent } \\
\text { 2. Weak } \\
\text { 3. Medium } \\
\text { 4. Strong }\end{array}$ & $\begin{array}{c}\mathrm{Ab} \\
\mathrm{Wk} \\
\mathrm{Me} \\
\mathrm{St}\end{array}$ \\
\hline 5. Recurved flag leaf & $\begin{array}{l}\text { 1. All } \\
\text { 2. Half } \\
\text { 3. Three forth }\end{array}$ & $\begin{array}{c}\text { All } \\
\mathrm{H} \\
\mathrm{TF}\end{array}$ \\
\hline 6. Stem width & $\begin{array}{l}\text { 1. Narrow } \\
\text { 2. Medium } \\
\text { 3. Broad }\end{array}$ & $\begin{array}{c}\mathrm{N} \\
\mathrm{Mi} \\
\mathrm{B}\end{array}$ \\
\hline 7. Leaf width & $\begin{array}{l}\text { 1. Narrow } \\
\text { 2. Medium } \\
\text { 3. Broad }\end{array}$ & $\begin{array}{c}\mathrm{Nr} \\
\mathrm{Md} \\
\mathrm{Br}\end{array}$ \\
\hline 8.Leaf colour & $\begin{array}{l}\text { 1. Light } \\
\text { 2. Medium } \\
\text { 3. Dark }\end{array}$ & $\begin{array}{c}\mathrm{L} \\
\mathrm{Mn} \\
\mathrm{D}\end{array}$ \\
\hline 9. Panicle attitude & $\begin{array}{l}\text { 1. Erect } \\
\text { 2.Semi erect } \\
\text { 3. Drooping }\end{array}$ & $\begin{array}{l}\text { Er } \\
\text { Ser } \\
\text { Dr }\end{array}$ \\
\hline
\end{tabular}




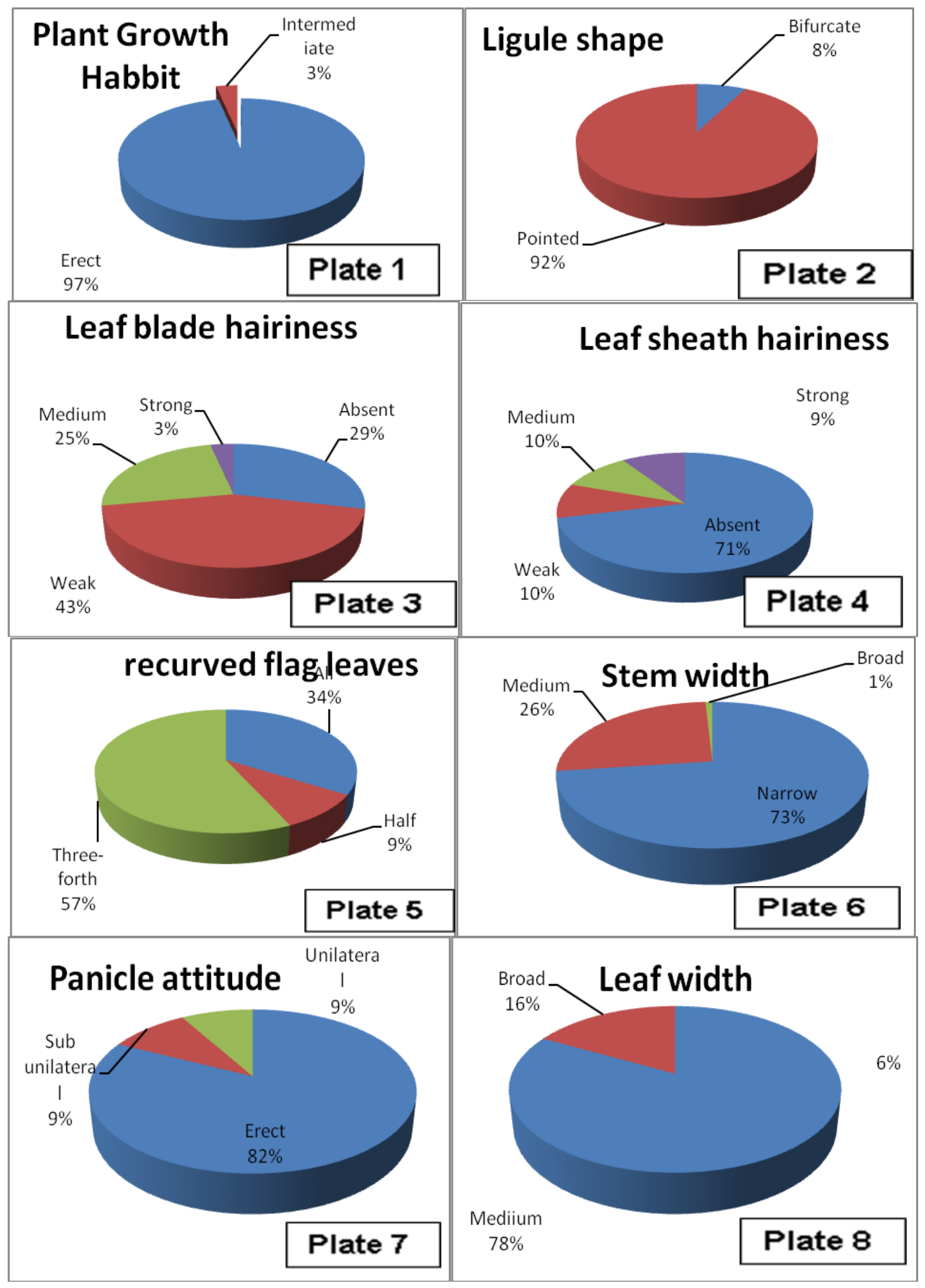




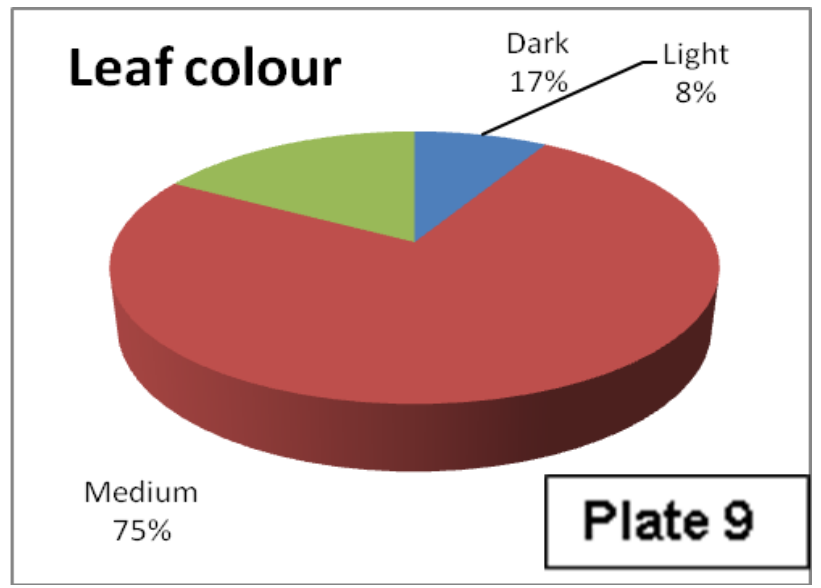

For plant Growth habit, out of 118 lines studied, 114 lines were erect type and only 4 had intermediate type (Plate 4.1). In case of ligule shape 109 lines were grouped as pointed type of ligule and 9 lines had grouped into bifurcated type of ligule (Plate 4.2). About leaf sheath hairiness84 lines did not have leaf sheath hairiness, 11 lines classified as weak, 12 lines denoted as medium and 11 lines had into strong lowest leaf (Plate 4.3).

For leaf blade hairiness 34 lacked the hairiness of margin below flag leaf, 51 lines grouped into weak, 29 lines classified into medium and 4 lines had strong leaf blade hairiness of margin below flag leaf (Plate 4.4). Like that for recurved flag leaf 40 lines had 100 percent frequency of recurved flag leaf, 11 lines had nearly 50 percent frequency and 67 lines had about 75 percent frequency of plants with recurved flag leaf (Plate 4.5).

For about stem width out of 118 lines studied 86 had narrow type stem, 31were medium type and only a single mutant line possessed broad stem (Plate 4.6). For leaf width only 7 lines grouped into narrow type leaf, 92 lines had medium type leaf and 19 lines were found to have broad leaf (Plate 4.7). In case of leaf colour 10 lines are classified into light green colour leaf, 88 lines grouped into medium green color leaf and 20 are comes under dark green color leaf (Plate 4.8). While for Panicle attitude 97 lines had erect panicle attitude type, 11 had sub unilateral type and 10 had unilateral type of panicle attitude (Plate 4.9).

\section{References}

Arora RN, Bisht SS, Joshi UN and Jhorar BS. 2008. Evaluation and characterization of oat germplasm. Forage Research 34: 2932

Greene NV, Kenworthy KE, Quesenberry KH, Unruh JB and Sartain JB. 2008. Diversity and relatedness of common carpet grass germplasm. Crop Science 48: 2298-2304.

Oliver RE, Obert DE, Hu G., Bonman JM and Jackson EW. 2010. Development of oatbased markers from barley and wheat microsatellites. Genome 6: 458-471.

Rines HW, Molnar SJ, Tinker NA and Phillips RL. 2006. Oats. In: Cereals and millets: genome mapping and molecular breeding in plants (CKoleed). Springer Berlin Heidelberg, New York 211-242.

\section{How to cite this article:}

Kavita Gupta and Mehta, A.K. 2018. Morphological Characterization of Advanced Mutant Lines of Oat (Avena sativa L.). Int.J.Curr.Microbiol.App.Sci. 7(11): 209-212. doi: https://doi.org/10.20546/ijcmas.2018.711.025 